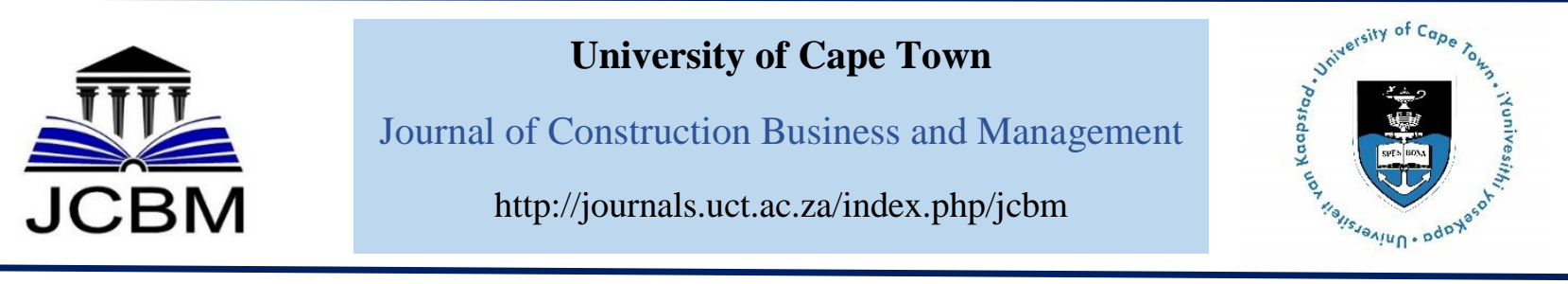

\title{
Assessing Quality Management Practice in Nigerian Construction Industry
}

\author{
U. Abdullahi ${ }^{1}$, S. A. Bustani ${ }^{2}$, A. Hassan ${ }^{3}$, F. E. Rotimi ${ }^{4}$ \\ ${ }^{1 \& 3}$ Department of Building, Modibbo Adama University of Technology, Yola, Nigeria, ${ }^{2}$ Department of Quantity \\ Surveying, Bayero University, Nigeria, ${ }^{4}$ Building Environment Engineering Department, Auckland University of \\ Technology, Auckland, New Zealand
}

Received 14 March 2018; received in revised form 10 April 2018, 24 October 2018; accepted 30 October 2018. https://doi.org/10.15641/jcbm.3.569

\begin{abstract}
Several adverse reports on quality performance drive the need to assess quality management practice in the Nigerian construction industry. Incidences of building failures and in extreme cases, building collapse have been attributed to poor quality management among other factors. This paper assesses the quality management practices of Nigerian construction firms intending to suggest appropriate courses of action for improving quality performance. Data were collected through questionnaires administered to management staff in 20 construction firms in Abuja, Nigeria. Findings from the study show that inspections and statistical quality control techniques are the most widely used quality management tools by construction firms in Nigeria. However, the study found that the preparation of quality management plans (QMP) and quality auditing (a measure of quality assurance in building production), is not popular among Nigerian construction firms. Inadequate planning arrangements for quality, poor communication of quality requirements and lack of awareness of the benefits of quality management were identified as the most significant issues affecting quality management practice. Therefore there is a low uptake of quality management practice principles within construction organizations in Nigeria. Hence, the need to create awareness for implementing quality management principles and concepts in its construction industry.
\end{abstract}

Keywords: Assessment, Construction industry, Nigeria, Quality management, Quality standards

\section{Introduction}

A construction project is considered successful when it is completed on time, within budget, following specifications and to stakeholders' satisfaction. However, levels of project performance and project successes are low in the construction industry especially in developing countries such as Nigeria where owners are generally dissatisfied (Odediran, Babalola \& Adebiyi, 2013; Isa, Jimoh \& Achuenu, 2013). One of the significant reasons for owners' dissatisfaction with building projects is their poor quality (Abdulrahman, Wang \& Wen, 2010; Achi, Onukwube \& Ajayi, 2007). Every customer wants a quality product that meets its needs and worth the value of money it has invested unto the product (Achi et al., 2007). Therefore customers tend to be satisfied when quality product and service are delivered to them. Project executors need to understand customer's need and requirement so that both their stated and implied quality levels can be met at all times. Understanding customers need, and requirement could enable organisations to implement quality management practices and imbibe cultures which guarantee their customers' satisfaction. A strong commitment to quality and continuous companywide quality improvement will lead to significant improvement in quality performance and increased profit margins for any construction organisation. Poor performance has adverse effects which transcend the industry to impact on national growth and sustainable development (Windapo, 2006). Structural failure seems to abound in developing countries (Aini et al., 2005; Taiwo $\&$ Afolami, 2010) with worst cases resulting in building collapse with major causalities (Windapo \& Rotimi, 2012). In a nutshell, quality management practices have a direct impact on the level of client satisfaction, quality enhancement, elimination of rework, and the enabling

\footnotetext{
${ }^{4}$ Corresponding Author.

Email address: frotimi@northtec.ac.nz
} 
synergy between different project parameters (Smallwood \& Rossouw 2008; Alwi, Hampson \& Mohamed, 1999).

Building construction has become more complex, partly due to project owners' increasing demands and expectations. Hoonakker (2006) reported that the construction industry's clients are demanding improved quality of service, faster buildings and innovations in technology. As a result, building products and systems have had to become more innovative to meet the owner's demands. However, newer and innovative procurement processes bring about challenges which building contractors need to manage effectively while delivering value to the project owner. Also, with the advent of globalization, construction firms are striving to achieve internationally accepted quality levels to ensure their forefront position in emerging international markets. Hence the need for a proper system that provides more quality when compared to other project objectives (Abdul Rahman et al.; 2010).

Burati, Matthews and Kalindi (1992) describe quality as the conformance to certain performance requirements. This entails meeting up the legal, aesthetic and functional requirements (Arditi \& Gunaydin, 1997). A more universally accepted definition of quality, however, is the one provided by the International Standard Organization (ISO8042, 1994). The ISO defines quality as the totality of features and characteristics of a product or service that bear on its ability to satisfy stated or implied needs. From a construction perspective, quality could be defined as the totality of characteristics that a constructed facility and the process involved in its construction should have; and enables the facility to meet or exceed customers' needs, requirements and other performance criteria (Love \& Irani, 2002). The preceding shows that determining and achieving customer requirements and expectations require proper quality management practice so that organisations can manage their current situation and future needs. Particularly in the new global economy, quality management practice has become a central issue for performance improvement within construction industries. However going by abysmal practices in developing economies such as Nigeria, it is pertinent that an assessment of quality management practices will benefit its construction industry. The current study investigation is, therefore, relevant as it provides a snapshot of current practices and identifies why and how quality management can be improved in the Nigerian context.

\section{Literature Review}

\subsection{The characteristics of the construction industry}

The construction industry has many characteristics that set it apart from other production environments, especially when compared with other sectors such as manufacturing (Kamal, Yusof \& Iranmanesh, 2016). The characteristics that make construction project a complex undertaking include: its fragmented nature, uniqueness, dynamism, non-standardisation, communication difficulties and the lack of customer focus of the construction industry (Davis, 2007; Egan, 1998). A typical project has a combination of persons and organizations including architects, engineers, quantity surveyors, planners, contractors, suppliers and other associated persons and organisations (such as the local council, building control agencies). These large numbers of project participants with differing quality objectives are expected to work together towards a common goal of project success. Setiawan et al. (2012) note that the complexity of construction projects is as a result of the resources employed, the environment in which construction takes place, the level of scientific knowledge required, and the number and interaction of different workflows. This sometimes leads to difficulties in quality achievement throughout the supply chain. Rowlinson and Walker (1995) point out that the construction industry is also characterized by its non-standardization, where production processes are, to some extent, different from one another. Hence, no universal standard or specification can be applied to the product. According to Love, Holt, Shen and Irani, (2002), both the internal and the external environment of construction projects are dynamic and relatively unstable. Therefore such environments could hinder the smooth application of quality management practice. Within the context of the current study, some of these characteristics impacts on quality management practice hence affect the ability to meet quality objectives desired by project owners, users and compliance authorities. Very often, these characteristics make successful project outcomes ambiguous (Chan \& Chan, 2004).

\subsection{Building collapse in Nigeria}

One of the most significant current discussions among building owners, governments, approving authorities and professional bodies is the increasing incidence of building collapse in Nigeria. Dimuna (2010) and Ede (2010) pointed out that the frequency of building failures and in extreme cases, building collapse in Nigeria has become alarming and worrisome. Several other studies have reported the continuous increase in building collapse in Nigeria, with the most affected areas being urban areas because of their population growth rate. For example, Windapo (2006) study on 61 cases of building collapse between 1974 and 2006 found that the highest incidents of building collapse occurred in Lagos State. Of the study cases, $40 \%$ were residential buildings (Windapo, 2006). Another analysis by Dimuna (2010) shows that between 1975 and 1995, of 26 incidences of building collapse recorded, 14 between 1982 and 1996, and ten occurrences were recorded between 2004 and 2006 in Lagos State alone. Ede (2010) investigated 47 cases of building collapse in Abuja, Lagos and Port Harcourt between the periods of 2000 to 2010. The study also found Lagos State to have the highest incidences of building collapse. These findings are unanimous about Lagos State having the highest rates of building collapse. In summary, building collapse is significant in the construction industry in Nigeria. These result in significant casualties and loss of lives that could be avoided. The implementation of efficient and effective quality management principles in construction organisation could bring an end to the needless loss of lives. There are suggestions for the construction industry to examine the competency and effectiveness of construction site workers as well as the standards of the materials and components used in 
building construction (Oke \& Abiola-Falemu, 2009; Taiwo \& Afolami, 2010). Coupled with this is the establishment and implementation of sound quality management systems that would improve process performance across all construction activities (Rotimi \& Tookey, 2012).

\subsection{Quality management systems in construction}

Quality management systems have therefore become the focal points in businesses within the construction industry (Smallwood \& Rossouw, 2008) Quality management system according to the ISO 8402, (1994), refers to all management functions that determines quality policy, objectives and responsibilities, and implements them by means such as quality planning, quality control, quality assurance, and quality implementation within any quality system. The quality management system establishes a framework of reference points that ensure that every time a process is performed, the same information, methods, skills and controls are used and applied in a consistent manner (Dale, 2003). Essentially a quality management system standardises organisations' processes, helps to minimise waste and reworks, and increase organisations' profit margin (Wilkinson \& Scofield, 2010). This management discipline is concerned with preventing problems from occurring by creating the attitudes and controls that could make prevention possible. According to Nicholas and Steyn (2008), a good quality management system is crucial in ensuring compliance with the quality criteria of projects. In other words, the quality management system is the criteria by which organisations' quality performance are measured and for which quality management standards were developed. It is now used by many in the construction industry to ensure that the right things are done right the first time. Abdulrahman (1996) suggests that minimizing errors/mistakes during the delivery of goods and services is possible with the introduction of formal quality management systems to plan, monitor and control production processes.

Toward this end, a series of international quality management standards have gained wide acceptance in the construction industry. The International Organisation for Standardisation (ISO) for example, emerged during the last two decades as a system that can be applied to different types of organisations in order to obtain improvements in quality procedures and products. The ISO's initial sets of standards have been progressively developed to be relevant to construction due to its generic nature (Chini and Valdex 2003). The ISO creates an assurance regime that provides confidence that an organisation has a quality process installed and that the organisation provides consistent products that will meet its customers' needs and other regulatory requirements. Love and Li (2000) state that such implementation leads to third party certification that a product / service performs to requirements and provides evidence that an optimal level of quality is achieved. Quality is about meeting standards and end user requirements. A quality management standard like the ISO has a customer focus in all its requirements (Rotimi, 2013). The probability of meeting customers' needs is higher when such a standard, guides quality management performance. ISO 9000 sets the minimum standard for quality management systems and many organisations have become ISO 9000 compliant as a result of pressure from their customers (Kumaraswamy \& Dissanayaka, 2000); although these clients tend to be public sector based that build one-off projects.

In Nigeria, the Standards Organization of Nigeria (SON) has formally adopted the ISO 9000 for quality management in the country (Achi et al., 2007). Although there is anecdotal evidence,that suggest that its implementation is not clearly evident in the Nigerian construction industry. The current study assesses quality management practice and attempts to identify the factors that may be preventing its implementation in the Nigerian construction industry. The authors reflect that to achieve a quality assured construction performance, construction organisations need to be consistent in their pursuit of quality. However consistency can only be achieved through a documented quality management system, which effectively incorporates quality control, assurance and quality improvement.

\subsection{Quality management process}

According to Smallwood and Rossouw (2008), the quality management process commences with the production of a quality management plan which needs to be submitted along with tender documents during the initial stages of a construction project. There are three major processes involved in the management of quality in construction projects (Nicholas \& Steyn, 2008; PMI, 1996). These are quality planning, quality assurance and quality control. Each of these processes is briefly described in the following sub-headings.

2.4.1 Quality Planning ( $Q P)$

$\mathrm{QP}$ is essentially a process that guides future quality activities. It sets the requirements and standards to be met as well as the actions necessary to meet those requirements and standards. The quality of a project is assessed by conformity to a quality plan designed to meet customer needs. According to Nicholas and Steyn (2008), quality planning provides the confidence that all steps necessary to ensure quality have been thought through. It involves identifying which quality standards are relevant to the project and determining how to satisfy them (PMI, 1996). The quality plan specifies the requirements to be met in each project phase, getting approvals before continuing to the next phase. For example, it specifies at what stage formal design reviews could be held, how quality assurance would be managed for work done by subcontractors, as well as when and how deliverables will be inspected (Nicholas \& Steyn, 2008). The quality plan could also indicate the quality techniques that would be used and when. Checklists are usually incorporated as part of the quality planning process to verify that a set of required steps have been performed (PMI, 1996). Organisations in more developed economies have a standardized checklist for ensuring consistency in activities performed frequently.

2.4.2 Quality Control (QC)

Quality control (QC) describes an ongoing process of monitoring and appraising work, and taking corrective action so that quality outcomes that are planned for could be achieved (Nicholas \& Steyn, 2008). QC is essentially the activities and techniques employed to achieve and 
maintain the quality of a product, process, or service by monitoring activities, finding and eliminating causes of quality problems so that the requirements of the customer are continually met. QC is thus, primarily concerned with defect detection. The main $\mathrm{QC}$ techniques are related to inspection and statistical quality control (statistical sampling). The results of these processes are used in taking corrective actions and to inform the quality assurance (QA) process, so steps can be taken to prevent similar errors and defects (Kemp, 2006). Other QC techniques are control charts and flowcharts.

Inspections involve checking that what is produced is what was required (Harris \& McCaffer, 2002). The inspection takes two forms in construction works: that which is quantifiable for example lines, levels, verticality and dimensions; and that which is open to inspectors' interpretation such as fitness, tolerance, cleanliness and visual checks (Harris and McCaffer, 2002). Quality checks for construction performance are undertaken by work supervisors to ensure they comply with specifications. Inspections do not of themselves prevent or correct mistakes unless appropriate corrective measures are taken subsequently. On the other hand, statistical sampling involves choosing a part of a population of interest and subjecting them to checks, tests or inspections (PMI, 1996). The result of tests on a small sample helps to establish the acceptability of an entire lot or batch of materials or work products (Hendrickson \& $\mathrm{Au}, 2008)$. Each lot tested, determines whether they satisfy a minimum acceptable quality level (AQL). Testing the cube strength of concrete is a typical example of statistical sampling in construction. Appropriate sampling can often reduce the cost of quality control (PMI, 1996).

\subsubsection{Quality Assurance (QA)}

Quality Assurance is a more modern approach to quality achievement in production. It is a shift from the old inspection and quality control systems where a lasting and continuous improvement in quality is achieved by directing organizational efforts towards planning and preventing problems occurring at the source (that is a shift from detection towards the prevention of nonconformance). Thus quality assurance (QA) seeks to eliminate errors and mistakes that will give rise to wastes and defects and subsequently avoid reworks through replacement and making good the defects. QA is broadly the prevention of quality problems through planned and systematic activities. These include the establishment of sound quality management systems, the assessment of its adequacy, the audit of the operation of the system and the review of the system itself (Harris \& McCaffer, 2002). The PMI (1996) describes QA as all the planned and systematic activities implemented within a quality system to provide confidence that projects will satisfy relevant quality standards. 'Fitness for purpose' and 'right first time' are the basic principles of QA to ensure that specifications are consistently met (Harris \&d McCaffer, 2002). QA concentrates on production or construction management methods and procedural approaches to ensure that quality is built into the production system. QA may be provided to the project management team or management of performing organisation as internal quality assurance; or provided to customers and other parties not actively involved in project execution as external QA (PMI, 1996). Quality planning tools and quality audits are the basic techniques used for providing QA. Quality audit is simply a structured review of other quality management activities (PMI, 1996). A quality audit examines the elements of a quality system to evaluate how well these elements comply with quality system requirements. The elements of a quality system identified by Harris and McCaffer (2002) include responsibilities, authorities, relationships, functions, procedures, processes and resources. The main objective of any quality audit is to identify lessons learnt that could improve the performance of the project or other projects within an organisation (PMI, 1996). It helps to establish how well a system is working (Nicholas \& Steyn, 2008).

\subsection{Factors affecting the application of quality management practice}

Quality management practices have fallen short of expectations in the construction industry. Love and $\mathrm{Li}$ (2000) affirm that the lack of attention to quality assurances within the construction industry has resulted in quality failures becoming endemic features of the industry. Poor quality management is profound in developing countries. For example, Joubert, Cruywagen and Basson(2005) found that a disregard of quality management implementation exists within the South African construction industry. In Nigeria, poor quality management within its construction industry has led to many years of poor customer satisfaction and service delivery (Achi et al., 2007). Some of the factors affecting the practice of quality management highlighted by Said et al. (2009) include lack of commitments to quality, inadequate support from management, poor attention to quality issues and poor planning for quality. There is no doubt that there is a current and indeed pressing need to examine the implementation of quality management in many construction industries. Considering the situation in Nigeria is relevant with particular emphasis on the level of implementation and factors that impact on the implementation of quality management practices.

\section{Research Approach}

There are various methods of data collection for a study, but the method adopted depends on the nature of the information required and other circumstances relevant to the topic or study area. There is no one perfect method; instead, any approach that will provide the required information is suitable. The literature review section of this paper shows that quality management practice in the Nigerian construction industry needs to improve and that there are factors that affect the proper implementation of quality management activities in construction organisations. The status of quality management practice is rarely surveyed or examined in the context of construction industry performance evaluation (Rotimi, 2013). To address the objective of assessing quality management practice, a survey of construction practitioners was deemed fit for the study. Questionnaires were used as a survey instrument to widen participation, as they are ideal instruments in survey research approaches (Kumar, 2011). Structured questionnaires 
were administered to construction companies based in Abuja, the capital city of Nigeria. Abuja was selected for its proximity and because of the numerous housing development projects undergoing construction. The research participants were management staff within medium to large construction firms, as these could provide the necessary information on their respective organisations' quality management practices. A total of 76 questionnaires were administered, out of which 41 were returned in completed form for the analysis. The total number of completed questionnaires gives an overall response rate of $54 \%$.

\subsection{The questionnaire}

The questionnaire comprises three key sections. The first section captures demographic information about the survey participants. The second section covers questions to determine the extent of the usage of some quality management tools within the construction industry. The questions were based on mostly four-point scales from 1 to 4, corresponding to 'Never Used', 'Occasionally', 'Usually' and 'Always Used' respectively. The third section elicited the participant's perceptions of the factors affecting quality management practice within the construction industry. The responses were measured on a five-point scale from 1 to 5 , corresponding to 'Strongly Disagree', 'Disagree' 'Neutral', 'Agree', and 'Strongly Agree' respectively.

In analysing and evaluating the result of the study, descriptive statistics using frequencies, percentages and Mean Scores (MS) were used. To facilitate the use of the Mean Score formula, numerical values were assigned to the responses. The mean score was calculated using the formula::

$$
M S=\frac{\sum F x}{\sum F}
$$

Where: $M S=$ Mean Score, $F=$ Frequency of response to each factor and $x=$ Weighted score given to each rated factor.

\section{Results and Discussion}

\subsection{Demography of research participants}

Table 1 gives a breakdown of the demographic information collected from the research participants. From the table, it could be observed that five categories of management staff participated in the research. Their designations show that $12.20 \%$ are project managers, $26.83 \%$ are construction managers. Site engineers and site supervisors' constitute $21.95 \%$ and $29.27 \%$ of the respondents and $9.76 \%$ of the respondents are lower-level site management personnel (such as foremen). A large percentage of the respondents $(58.53 \%)$ have over ten years of working experience in the construction industry.

Concerning their background qualifications, the table gives a breakdown showing that $36.59 \%$ of the respondents are builders by profession, and $24.39 \%$ are civil/structural engineers. Architects and quantity surveyors constitute $9.76 \%$ each of the survey respondents. The majority $(41.46 \%)$ of the respondents are Bachelor's degree holders, $26.83 \%$ with HND and $9.76 \%$ of them with Diploma qualifications. Only $7.32 \%$ have postgraduate qualifications. The demography presented shows that the respondents are qualified to provide valuable contributions to the research, due to their professional backgrounds, experience and education.

Table 1: Characteristics of the survey respondents

\begin{tabular}{|c|c|c|c|}
\hline Respondents characteristics & & Frequency & Percentage \\
\hline \multirow[t]{5}{*}{ Designation of respondents } & Project Managers Construction & 5 & 12.20 \\
\hline & Managers & 11 & 26.83 \\
\hline & Site engineers & 9 & 21.95 \\
\hline & Site supervisors & 12 & 29.27 \\
\hline & Others & 4 & 9.76 \\
\hline \multirow[t]{5}{*}{ Working Experience } & $0-5$ Years & 7 & 17.07 \\
\hline & $6-10 ،$ & 10 & 24.39 \\
\hline & $11-15$ “ & 7 & 17.07 \\
\hline & $16-20$ “ & 8 & 19.51 \\
\hline & Above 20 years & 9 & 21.95 \\
\hline \multirow[t]{5}{*}{ Profession } & Architects & 4 & 9.76 \\
\hline & Builders & 15 & 36.59 \\
\hline & Civil/structural engineers & 10 & 24.39 \\
\hline & Quantity surveyors & 4 & 9.76 \\
\hline & Others & 8 & 19.51 \\
\hline \multirow[t]{5}{*}{ Education } & M.Sc. & 3 & 7.32 \\
\hline & PGD & 6 & 14.63 \\
\hline & B.Sc. & 17 & 41.46 \\
\hline & HND & 11 & 26.83 \\
\hline & OND and others & 4 & 9.76 \\
\hline
\end{tabular}

\subsection{The use of quality management tools}

This section of the result shows the level of use of some quality management tools. Respondents in the survey were requested to indicate how well the tools were used on their respective construction projects. 
Table 2 gives a summary of the responses and the respective ranking of quality management tools in line with their frequency of usage. The Mean score

Table2: Frequency of using quality management tools in the Nigerian construction industry

\begin{tabular}{llcccc}
\hline S/n & \multicolumn{1}{c}{ Quality Management Tools } & $\sum \mathbf{F}$ & $\sum \mathbf{F}_{\mathbf{x}}$ & Mean & Rank \\
\hline 1 & Inspection ( materials, components and construction processes) & 41 & 143 & 3.49 & 1 \\
2 & Statistical sampling ( Test on materials and component) & 41 & 126 & 3.07 & 2 \\
3 & Quality Checklist (materials and processes) & 41 & 109 & 2.66 & 3 \\
4 & Use of Quality management plans & 41 & 101 & 2.46 & 4 \\
5 & Issuance of clear work instructions on site & 41 & 93 & 2.27 & 5 \\
6 & Quality auditing & 41 & 83 & 2.02 & 6 \\
\hline
\end{tabular}

The results show that that inspection of materials/components and construction processes was ranked as the most commonly used quality tool by construction firms within the study area (mean $=3.49$ ). The result agrees with the findings by Elsawalhi and Enshassi (2004) on the use of quality management tools within the Malaysian construction industry. Elsawalhi and Enshassi (2004) had identified that inspection was the most commonly used quality management tool by contractors in Malaysia.

The study result shows that statistical sampling (e.g. testing of materials and components) was ranked second, with mean value equals to 3.07. Quality checklist (for materials and construction processes) and use of quality management plans at the onset of every project were ranked third and fourth quality management tools consecutively. Quality auditing was ranked the least quality management tool by the survey respondents. The low ranking of the quality management plan and quality audit seem to suggest that construction firms have not yet fully imbibed the modern concept of quality assurance. Without quality audits, it is difficult to assess quality performance, talk less of being able to provide the necessary feedback that could improve practice. Thus quality improvement, which is the primary objective of quality assurance (PMI, 1996), may seem farfetched in the Nigerian construction industry.

\subsection{Factors affecting quality management practice}

calculations facilitated the ranking for each quality management tool.

Table3: Factors affecting implementation of quality management in the construction industry

\begin{tabular}{llllll}
\hline S/n & Factors affecting the application of quality management & $\sum \mathbf{F}$ & $\sum \mathbf{F x}$ & Mean & Rank \\
\hline 1 & Lack of awareness on the benefits of quality management & 41 & 152 & 3.71 & 3 \\
2 & High cost of implementing quality management & 41 & 144 & 3.51 & 4 \\
3 & Inadequate/Lack of planning for quality & 41 & 164 & 4.00 & 1 \\
4 & Lack of commitment/support from top management & 41 & 140 & 3.41 & 6 \\
5 & Poor documentation procedures on quality issues & 41 & 130 & 3.17 & 10 \\
6 & Lack of attention to quality/ inadequate supervision & 41 & 137 & 3.34 & 8 \\
7 & Poor communication of quality requirements among the project team & 41 & 153 & 3.73 & 2 \\
8 & Inadequate motivation of workers for achieving desired quality level & 41 & 143 & 3.49 & 5 \\
9 & Lack of clear assignment of responsibility among project members & 41 & 134 & 3.27 & 9 \\
10 & Inadequate training/education of construction workers & 41 & 138 & 3.37 & 7 \\
\hline
\end{tabular}

\section{Discussion of Findings}

It seems apparent from the study findings that key quality management tools are not being used in the construction
The surveyed respondents were sought to rate the factors affecting quality management practice within the construction industry in Nigeria. The result and analysis are presented in Table 3 . The result shows that inadequate / lack of planning for quality management in the construction industry was ranked as the most significant factor affecting quality management practice in the construction industry. The calculation of the mean score generated a value of 4.00 . Hence it is perceived as the most significant factor. Immediately following planning inadequacies are poor communication of quality requirements among project team members (mean score = 3.73) and lack of awareness of the benefits of quality management (mean score $=3.71$ ). Other factors affecting quality management practice include the high cost of implementing quality management (mean score $=3.51$ ); inadequate motivation of workers to achieve desired quality levels (mean score $=3.49$ ); and lack of commitment from top management (mean score $=3.41$ ). Poor documentation procedures on quality issues (mean score $=3.17$ ) and lack of continuous professional development among project team members (mean score $=$ 3.27) were the least significant factors affecting quality management practices in the construction industry.

On the whole, the results suggest a generally poor quality management practice with numerous factors contributing to this situation. It would also seem that the priority attached to quality is low compared to other project objectives. 
However, this is not the case as a quality management plan was ranked comparatively low to other quality management tools. Quality auditing that could provide useful feedback on quality performance was also ranked low, suggesting that there is no desire for improved performance within the Nigerian construction industry. Inspection of materials/components and construction processes is the most commonly applied quality tool by their construction firms. This could suggest that traditional quality management concepts (inspections and statistical sampling) still have wide applications within the industry. This may mean that quality considerations are essentially about the control of the effect rather than preventative and continuous improvement approaches that have been suggested as the way forward in quality management practice in more developed construction industries.

The study findings show that numerous factors affect quality management practice in the Nigerian construction industry. Chief of these factors was inadequate/lack of planning for quality, poor communication of quality requirements and lack of clear awareness on the benefits of quality management. These factors are significant and would require to be addressed by whole-of-industry. Quality planning deserves particular focus by construction professionals, government and its compliance agencies. Imbibing quality assurance principles would mean much more planning of quality issues before their actual performance in Nigeria. These practice inadequacies may be responsible for the incidences of building failure, reputation issues and the high levels of client dissatisfaction with the products of the industry.

\section{Conclusion}

The paper has as a key objective, an assessment of quality management practice within the construction industry in Nigeria. The study investigation also establishes the factors affecting the implementation of quality management principles within the industry. The study has primarily met these objectives. On the whole, the findings are suggestive of a generally poor quality management practice in Nigeria. Quality management plans are rarely produced for construction projects, talk less of follow on quality auditing to assure project owners. Numerous

\section{References}

Abdul-Rahman, H. (1996). Some observations on the management of quality among construction professionals in the UK. Construction Management \& Economics, 14(6), 485-495.

Abdulrahman H., Wang C. and Wen Y.X. (2010). How professional ethics impacts construction quality. Scientific Research and Essays, 5(23): 3742-3749.

Achi, O.F., Onukwube H.N, Ajayi O.M. (2007). An assessment of quality management of building projects in Nigeria. Proceedings: Construction and Building Research Conference. Royal Institute of Surveyors (COBRA). Georgia Tech. Atlanta USA, 6-7 September.

Alwi, S., Hampson, K. and Mohamed, S. (1999.) Investigation into the relationship between rework and factors contribute to this situation, but chief amongst this poor quality planning and poor communication of quality requirements amongst project execution teams. Essentially quality management and control is pursued after the effect rather than preventative and continuous performance improvement. The priority attached to quality achievement seems low compared to other project objectives in Nigeria.

These are conclusions that may not be generalisable considering the relatively small size (and localized data from one Nigerian city) used for the study investigation. More extensive data could have enabled a more rigorous statistical analysis to have been undertaken from which more reliable inferences could have been generated. Simply the current study deserves further confirmatory investigations.

However, within the limitations of the current study findings, the study recommends improvement in quality management practices within the construction industry in Nigeria. The responsibility for this lies with project stakeholders. Everyone must play their part; the client must understand that they are a part of the building production process and clearly define their requirements. Designers must ensure they have interpreted those requirements and specify the criteria for quality achievement. The contractors must fully accept that all project scope/quality requirements are achievable and be committed to it. Quality management practices need to meet minimum benchmark requirements.

For any reasonable quality improvements to be visible in the Nigerian construction industry, contracting organisations need to set up quality departments that will plan, control and monitor quality on and off-site. Such departments that operate within the medium to large organisations in the sector will supervise all testing and control processes; take charge of all records on quality, and provide timely responses to operational teams. Furthermore, attitudinal changes are required of professionals within the construction industry. All project participants should recognise that implementing proper quality management will give them both a competitive advantage and also improve their collective reputation. Meeting clients' requirements the first time and every time within the complex processes of building production is achievable with right quality management practices.

site supervision in high rise building construction in Indonesia. The Second International Conference on Construction Process Reengineering, Sydney, July, 189195.

Arditi, D., \& Gunaydin, H.M. (1997). Total quality management in the construction process. International Journal of Project Management, 15(4): 235-243. doi:10.1016/S0263-7863(96)00076-2

Bamisile, A. (2004), Building Production Management. Lagos: Foresight Press Ltd.

Burati, J.L., Matthews M.F. and Kalindi, S.N. (1992). Quality management organizations and techniques. Journal of Construction Engineering and Management. 118(1): 112-128

Chan, A.P.C. and Chan, A.P.L. (2004). Key performance indicators for measuring construction 
success. Benchmarking: An International Journal. 11(2): 203-221.

Chini A.R and Valdez H.E. (2003). ISO 9000 and the US construction industry. Journal of Management and Engineering, 19(2): 69-77.

Dale, B. G. (2003). Managing Quality, 4th Edition, Blackwell Publishers, UK

Davis, J.L. (2007). Firm-level entrepreneurship and performance: An examination and extension of relationships and measurements of the entrepreneurial orientation construct. PhD Thesis, University Of Texas, Arlington.

Dimuna, K.O. (2010). Incessant incidents of building collapse in Nigeria: A challenge to stakeholders", Global Journal of Researches in Engineering, 10(4), 75-80

Ede, A.N. (2010). Building collapse in Nigeria: The trend of casualties in the last decade (2000-2010). International Journal of Civil and Environmental Engineering, IJCEE-IJENS, 10(06): 32-42.

Egan, J. (1998). Rethinking Construction. London: Department of the Environment, Transport and the Regions.

Elsawalhi N. and Enshassi A. (2004) Quality management practice in the Malaysian construction industry. Journal of the Islamic University of Gaza (Natural Science Series, 12(1): 97-111.

Harris, F. and McCaffer, R. (2002). Modern Construction Management, 5th Edition, EPP Books Services, 7-23.

Hendrickson C. and Au, T. (2008). Project Management for Construction: Fundamental Concepts for Owners, Engineers, Architects and Builders. World Wide Web Publications.

Hoonakker, P. (2006). Quality management in construction industry. Proceedings: ASQ World Conference on Quality and Improvement, Milwaukee, WI, 1-3 May.

Isa, R.B. Jimoh, R.A. and Achuenu, E. (2013). An overview of the contribution of construction sector to sustainable development in Nigeria. Net Journal of Business Management, 1(1): 1-6.

IS0 8042. (1994). Quality management and quality assurance- vocabulary, international organization for standardization ISO TC176 Collection Geneva Switzerland

Joubert, W., Cruywagen, J. H., \& Basson, G. A. J. (2005). Will the implementation of a total quality management system benefit South African construction companies? South African Journal of Industrial Engineering, 16(1), 29-40.

Kamal, E. M., Yusof, N. A., \& Iranmanesh, M. (2016). Innovation creation, innovation adoption, and firm characteristics in the construction industry. Journal of Science \& Technology Policy Management, 7(1), 43-57.

Kemp, S. (2006) Project Management Made Easy. Wisconsin: Entrepreneur Press Madison.

Kumar, R. (2011). Research Methodology: A Step by Step Guide for Beginners. Third Edition, London SAGE Publications Ltd.

Kumaraswamy, M.M. and Dissanayaka, S.M. (2000). ISO 9000 and beyond: From a Hong Kong construction perspective. Journal of Construction Management and Economics, 18: 783-796.

Love, P.E.D, Holt, G., Shen, L., Li, H., and Irani, Z. (2002). Using systems dynamics to better understand change and rework in construction project management systems, International Journal of Project Management, 20(6): 425-436.

Love, P.E.D. and Irani, Z. (2002). A project management quality cost information system for the construction industry, Information and Management, 40(7): 649-661.

Love, P. E., \& Li, H. (2000). Quantifying the causes and costs of rework in construction. Construction Management and Economics, 18(4), 479-490.

Nicholas, J.A. and Steyn, H. (2008). Project Management for Business, Engineering, and Technology: Principles and Practice. 3rd Edition, UK: ButterworthHeinemann.

Odediran, S.J, Babalola M.O. and Adebiyi H.A. (2013). Assessment of business development strategies in the Nigerian construction industry. Journal of Business \& Management, 2(1): 34-45.

Oke, A., and Abiola-Falemu, J. (2009). Relationship between building collapse and poor quality of material and workmanship. Paper presented at the meeting of the RICS COBRA Research Conference, University of Cape Town. 10th-11th September.

PMI. (1996). A guide to the project management body of knowledge. Project Management Institute, Pennsylvania.

Rotimi, F.E. (2013). An evaluative framework for defects in new residential buildings: The New Zealand case. PhD Thesis, Auckland University of Technology, New Zealand.

Rotimi, F. E. and Tookey, J. (2012). Stage building inspection: A possible solution to building failures in Nigeria. Proceedings of the WABER Conference. AbujaNigeria. 24-26 July. Pp. 1295-1306

Rowlinson, S.M. and Walker, A. (1995). The Construction Industry in Hong Kong. Hong Kong: Longman.

Said, I., Ayub, A.R., Abd Razak, A. and Tee, K.K. (2009). Factors affecting construction organisation quality management system in the Malaysian construction industry. http://eprints.usm.my/16080/1/Ilias_Said_2.pdf

Setiawan, H., Erdogan, B. and Ogunlana, S.O. (2012). Corporate entrepreneurship for contracting companies: The current issues. Smith, S.D (Ed). Proceedings: 28th Annual ARCOM Conference, Edinburgh, UK. 3-5 September 817-827

Smallwood, J. and Rossouw, J.H. (2008). The implementation of quality management systems in South African construction. Proceedings: RICS/COBRA Construction and Building Research Conference. Dublin, Ireland.

Taiwo, A. A., and Afolami, J. A. (2010). Incessant building collapse: A case of a hotel in Akure, Nigeria. Journal of Building Appraisal, 6(3-4), 241

Wilkinson, S. and Scofield, R. (2010). Management for the New Zealand Construction Industry, Prentice Hall, Auckland. 
Windapo A. (2006). The threat of building collapse on sustainable development in the built environment in Nigeria. Proceedings: National Conference on Sustainable Development and the Built Environment, Nigerian Institute of Building, Jos. 9-12 August, 59-65.
Windapo, A. O. and Rotimi, J. O. (2012). Contemporary issues in building collapse and its implications for sustainable development. Buildings, 2(3), 283-299. 